\title{
Selling Southern Places: An Examination of Delta's Sky Magazine City Profiles.
}

\author{
DARREN PURCELL \\ University of Oklahoma
}

CAYTON MOORE

University of Oklahoma

Delta's Sky magazine claims to be an influential outlet for entities trying to promote places to investors and tourists. Claiming nearly 6 million readers monthly, the magazine's profiles of cities, states and regions have the potential to reach the niche audiences that shape the spatial practices of firms and influence individual decisions on tourism expenditures. This paper explores how Sky promotes places in the text of these profiles through the dual use of digital humanities tools and close reading-based interpretation to address the following questions. First, we ask how is the South represented in the Sky profiles? Second, what themes are present in the profile texts, given that all places seek to address both unique elements while addressing common themes of importance to business? We find that place promotion practitioners use very similar themes that have been identified in the literature since the 1980s, primarily accessibility. Efforts to attract the creative class are also present in the Sky profiles. The South poses unique challenges to place marketers, and our findings show a convergence in how profiles tackle the concept of southern culture and identity as it is leveraged in many of the profiles.

RESUMEN: La revista Sky de Delta Airlines afirma ser una fuente importante para las entidades que intentan promover varios lugares para la inversión económica y también para el turismo.
Con más de seis millones de lectores mensuales, los perfiles Sky de las ciudades, los estados y las regiones tienen el potencial de llegar a audiencias específicas que dan forma a las prácticas espaciales de empresas e influyen las decisiones personales sobre los gastos en el turismo. Este artículo explora cómo el texto de Sky promueve varios lugares tras el uso dual de herramientas de humanidades digitales y una interpretación cercana basada en la lectura para abordar las siguientes preguntas. Primero preguntamos ¿cómo se representa el sur estadounidense en los perfiles Sky? Segundo, ¿cuáles son los patrones en el texto de los perfiles, dado que todo lugar trata de presentarse como único pero también importante para el negocio? Encontramos que profesionales de la promoción usan temas similares que se han identificado en la literatura desde los años 1980-sobre todo la accesibilidad. Los esfuerzos para atraer la clase creativa también se presentan en los perfiles Sky. El sur estadounidense plantea desafíos únicos para el marketing. Nuestros hallazgos muestran una convergencia en la forma en que muchos de los perfiles abordan el concepto de cultura e identidad del sur estadounidense.

KEYWORDS: Place Promotion, Place Branding, Text Analysis, South, Economic Development PALABRAS CLAVE: promoción de lugar, marca de lugar, análisis de texto, Sur, económico 
If you fly Delta Airlines, you have likely perused the Sky magazine provided in the seat pocket. Since 2010, the magazine has published profiles highlighting the characteristics of various cities, states, and regions. The goal is the creation of a place image that frames the entity as an attractive place to invest in, to expand business to, and even spend some leisure time (Sky Media Kit, 2018).

This paper examines the discourse employed in the city profiles of Sky magazine. This approach to examining place promotion and place branding differs from other geographical work in that most case studies examine a particular locale's efforts or look at macro-scale efforts across a range of media. We focus on one particular media outlet, Delta's $S k y$, as a unique outlet for place promotion activity. Sky's 2018 media kit claims that "6 million readers" are reached monthly, with a mission to, "Attract an active, influential and travel-ready audience with compelling content......Introduce readers to innovative and cutting-edge places.... Explore a broad range of worldwide cities and regions for our readers to discover [emphasis ours]." (Sky Mediakit, 2018). The Mediakit describes Sky's city profiles as a space to "Focus on economic development, tourism and key commerce sectors that contribute to growing economies-when and where it matters." (Sky Mediakit, 2018). Thus, the magazine positions itself as an effective outlet for place promotion content to attract investment and leisure dollars.

Selling a place requires something to sell, and the sense of place is the product. This study reflects questions about the leveraging of the product in the name of place promotion and place branding. We focus on written texts, exploring how Sky's profiles invoke the concept of "Southern" and how it is leveraged in the text. The South's image presents challenges to place marketers in terms of communicating opportunities in a positive way. These challenges include perceptions of racism and backwardness, as seen in various forms of popular culture that mine stereotypes and tropes for commercial gain (Cox 2011). Additionally, we review the way Sky describes aspects of places seen as relevant to a variety of place consumers, including, accessibility, business climate, and quality of life, along with tourism opportunities in conjunction with images of the South.

This paper begins with an abbreviated discussion of the literature, highlighting concepts that have been important to place promotion practitioners and scholars. We then shift the focus to the use of Southern imagery as it appears in place marketing literature. Next, a discussion of the construction of the text corpus and our analytical and interpretative techniques is provided. Using these techniques, we examine the Southern image in place promotion through Sky Magazine, closing with a discussion of dominant terminology and themes in economic development used side-by-side with or in place of images of the South.

\section{PLACE PROMOTION AND \\ CHALLENGE FOR SOUTHERN PLACES}

Geographers have been interested in the role of media in shaping understandings of places for several decades. Much of the early work focused on a variety of media texts and imagery (e.g., Burgess 
1982, Birdsall 1986, Zonn 1990, Goss 1993, Ward 1998). Others have focused on specific government efforts to shape place images. These emphasized place promotion and place marketing efforts by localities ranging in scale from cities (Young and Lever, 1997) to states and even entire countries (Ryan 1990, Purcell and Kodras 2001). These representational spaces (Lefebvre 1991) created by writers, photographers, advertisers and economic development specialists, fit into the activities of what is termed the neoliberal state.

David Harvey identified the shift in the state's role toward urban entrepreneurialism and promotion (Harvey, 1989). Neoliberal logic driving place promotion efforts relies on "an extremely narrow urban policy repertoire based on... place promotion" to secure public and private investment (Peck and Tickell, 2002). Specifically, it is not enough that the state provides the material and social infrastructure for capital accumulation. Rather, it must compete to lure capital and investment to a locale. No matter the scale of operation: city, county, region or state, governments compete to steer capital to their locales in the hopes of benefitting from embedding firms and attractions to support local economies. It should also be acknowledged that these efforts to change spatial practice are couched as "pragmatic", especially for cities, and their local elites, under the guise of the entrepreneurial state (Eisenschitz 2010).

The neoliberal drive of the state to foster these conditions then manifests in development strategies such as the fostering of the "creative class", promoting the attraction of entrepreneurs to the city by emphasizing culture and stimulation to be found within the city (Florida 2002). This relies heavily on the outward image of a city, distributed to a very specific class of professionals seeking to leverage the characteristics of place for comparative advantage, a demographic that Sky claims to be engaging with monthly.

Publication of these profiles is of political importance to local and regional development officials in order to demonstrate to local stakeholders their effort and success at placing information in the hands of potential place consumers. A Google search for "sky magazine" returns examples of officials trumpeting their inclusion in the magazine, including Tourism Alabama; Visit Roanoke Virginia; and Visit Helena (Arkansas). Symbolically, publication of a Sky profile stands as affirmation to the public that the polished outward image of the community is both appropriate and effective.

Geographers examining the idea of the South have focused primarily on cognition and perception of place (Alderman and Good 1997). The place promotion and place branding literature understand that both processes have material impacts on spatial practices. These impacts include decisions about which new markets will be invested in, where new plants will be built, and where one's leisure dollars will be spent. Within the United States, the South $^{1}$ is associated with a set of distinct imagery, a legacy of popular culture dating back over a century, consisting of advertising and marketing efforts emphasizing a 'moonlight and magnolias' image but also invoking the racist minstrelsy of black face radio shows and the hillbilly image for white musicians hailing from Appalachia and the Ozark regions (Cox 2011). For many, as Ayers points out, "The whole South appears to be a vast saucer of unpleasant associations." (Ayers 1996, p. 63). Yet, there is diversity within the construction of Southern identity. Ayers continues, 
"Southerners with something to sell traffic in difference, eagerly marketing any distinctiveness they can claim.... Culture is a great natural resource... Each state has found its unique vein. Virginia quarries its Jeffersonian period, while Georgia sells burning Atlanta.... Tennessee offers country music, Kentucky tenders bluegrass, and Louisiana hawks Cajun." (ibid, p. 66-67). These representations of the South are not generated in a vacuum solely by outsiders. Ayers discusses active image-making by images of the South as complex constructions reflecting Southern contributions:

The North and South have conspired to create each other's identity as well as their own. The South eagerly defines itself against the North, advertising itself as more earthy, more devoted to family values, more spiritual, and then furious to have things turned, to hear itself called hick, phony, and superstitious. The south feeds the sense of the difference and then resents the consequences.

(ibid, p. 66)

For outsiders, the practitioner must work to distance the place they serve from perceptions held by the market they wish to reach, and yet still situate it in the Southern context generally. Given that tourism is a major component of many Southern economies, the industry of making a "Southern" identity, one that is diverse and that can be tailored to reflect the subregions is important for various market segments.

Succinctly, promoting southern locales present challenges. Cox (2011) makes clear that through various media forms in the 1900s (e.g. movies, literature, advertising, and tourism) the worst of the South still remains in the minds of many, cultivated deliberately for profit and endures as a barrier to effectively selling places. Those working to attract industry faced the, "...persistent stereotype of the South as a backward, degenerate region." (Cobb, 1993, p. 93.) Issues of racism that contradicted claims that parts of the South were "too busy to hate" impacted firms' locational decisions (Powledge, 1965, in Cobb, 1993, page 128). Unfortunately, these issues are still extant, as racism that might dissuade investors and tourists is seen in marked imbalances across a variety of areas. For example, tourism advertising fails to reflect the diversity of the region (Alderman and Modlin 2012) despite the fact that African-Americans are a growing segment of the tourism market nationally. Media images of politicians protesting the Confederate flag being taken down and relocated or being used as one of a constellation of neo-Confederate symbols used to support the ideas of a mass shooter in South Carolina (Webster and Leib 2016) do little to promote positive associations with Southern places.

Despite this, the South has a history of successfully promoting itself for industrial development. Ward (1998, p. 156-162) traces the promotion of the "New South" in the post-war period. Atlanta created a coalition for "Forward Atlanta" in 1925 comprised of both local governments and the city's businesses. Their expenditure for advertising campaigns across the United States was large for the era $(\$ 130,000$ expended in Saturday Evening Post ads alone in 1926-27). Industrial giants responded, as General Motors built a factory and retailing giant Sears-Roebuck established operations in Atlanta as well (Ambrose 2017). Success in reframing Atlanta as an industrial location soon inspired a 
regional rival to start "Forward Richmond", competing for investment and tourism, but as Ward notes, the publicity advantage went to the city that boldly moved first (ibid, p. 159).

What we see in the Sky magazine profiles is the nexus of several processes. First, the neoliberal state is under pressure to be entrepreneurial, to create markets for the products it can foster, essentially the conditions for capital accumulation. Facets of the state, (e.g. economic development agencies, tourism offices), or publicprivate partnerships with chambers of commerce develop brands and images to be sold, working to place them in various media. Sky magazine puts these place brands in front of a disproportionately wealthy clientele with power to make location and investment decisions and with disposable income to be lucrative tourists.

The research questions we investigate approach place promotion processes as articulated in text from two directions. First, we focus on the leveraging of various images of the South as a discursive resource. Do all these locations identify as Southern in their profiles? Does the regional moniker (with the attendant baggage) serve as a resource for branding? In other words, despite the negative image the South may have in other regions, how is the idea of the South deployed to attract specific niche markets? Second, the literature review demonstrates there will be differences created and emphasized, despite the convergence of ideas about what is valuable and important to promote. The writers and magazine publishers form an epistemic community replete with norms of practice. This encompasses discursive practices ranging from the order of topics in the profiles ${ }^{2}$ to inclusion of concepts that the early place promotion literature states are a given no matter what entity is promoting itself (e.g. accessibility, centrality, and of course insisting on the existence of unique business or tourist culture).

\section{DATA AND METHODS}

Sky's publisher, MSP Communications, claims in its promotional literature aimed at advertisers, that the magazine has the greatest circulation with an affluent and influential readership ${ }^{3}$. Table 1 breaks down readership by sex, education level, levels of homeownership, household income and employment status. The ratio between women and men is $46 \%$ women and $54 \%$ men. Clearly the household income of the readership exceeds the median income of the United States $(\$ 57,617$ in 2016, See Guzman 2017), is more educated than average American (33 percent of Americans held a bachelor's degree or higher in 2015; Ryan and Bauman 2016), and represents the managerial class, which influences business decision including siting and operations decisions.

The text corpus was gathered from the magazine's "Profile" sections. While not published in every issue, rarely is a month missed without a profile, and the earliest profile included dates to 2010. The size of each profile varies, ranging from 90 pages in length for large cities like Atlanta to only 10 pages (Baton Rouge and Titusville). Utilizing optical character recognition software, we converted PDF prints of the profiles to text format (.txt files). Profile texts were validated individually to ensure that words were recognized correctly. The text selected comes only from actual authored sections where there is a clear by-line. Text from advertisements 
Table 1. Audience Characteristics for Sky magazine.

\begin{tabular}{ll}
\hline Readership by Sex & $46 \%$ women, $54 \%$ men. \\
Education & $81 \%$ college educated \\
& $21 \%$ hold a postgraduate degree \\
Homeownership & $74 \%$ owns a home, $58 \%$ own a home worth over $\$ 200,000$ \\
Household Income & Average income: \\
& $62 \%$ over $\$ 100,000$ \\
& $39 \%$ over $\$ 150,000$ \\
& $22 \%$ over $\$ 200,000$ \\
Employment & $42 \%$ in professional or managerial posts \\
& $12 \%$ are classified as top management \\
\hline
\end{tabular}

Source: Delta Sky Magazine 2018 Mediakit. http://deltaskymag.delta.com/Magazine/AdvertiseWith-Us/Downloads/Public/2017MediaKit_ROB_LR-(1).pdf

and photo captions was excluded on the grounds that the terms used were not the same form of discourse seen in the text. While this reduces the richness of the data as advertisements will use short phrases aimed at efficiently painting a picture of place, our focus is on the output of Sky magazine's editors and authors, and their efforts to shape information provided by locales into an effective conveyor of place characteristics.

This study employs a text visualization program, Voyant Tools, for the software's capabilities to visualize and search for text in a larger corpus (Voyant-tools.org, n.d.). The tools employed provide statistical summaries of files and the corpus in several categories, as well as text visualizations that assist in examination of vocabulary both within a particular text and across the texts in the corpus. We acknowledge that such digital humanities approaches have been controversial in the humanities (Kirsch, 2014) and have led many to reject digital humanities tools, and that these approaches have rarely permeated geography scholarship focused on textual interpretation (though see
Beauguitte, et al. 2015). Still, we contend that these tools allow for effective macroviews of the corpus (distant reading) while still maintaining a commitment to solid interpretative approaches (close reading) (Moretti, 2013).

Table 2 demonstrates the variation in the amount of text each profile comprises. The four Atlanta profiles comprise 44.4 percent of the corpus. The next largest are the two Columbia, South Carolina profiles at 7.4 percent. Profiles with under 3,000 words were usually 15 pages or fewer. The smallest profile by word count, Titusville, FL, consists of 10 pages, mostly comprised of advertisements.

In order to address our research questions, we examined several clusters of words we theorized would be used to signal certain concepts. For example, to examine how the South was deployed, the term "south" was searched for within the corpus as well as variations such as southern and southeast. This was done by searching with a truncation symbol, in this case an asterisk (*) following the end of the search "root". This search term then returns all results with any string of characters following the 
Table 2. Cities, states and regions profiled in Sky magazine, and their publication dates.

\begin{tabular}{lll}
\hline Destination Name/Abbreviation used in Text & Years Profiled & Number of Words per Profile \\
\hline Atlanta, GA (ATL) & 2010,2013, & $\begin{array}{c}12,308 ; 16,955 ; 14,370 ; \\
18,196 \text { respectively } \\
\text { (total of 61,641) }\end{array}$ \\
Baton Rouge, LA (BAT) & 2015,2017 & 2,092 \\
Cocoa Beach, FL (COC) & 2014 & 2,520 \\
Columbia, SC (COL) & 2016 & 6,$075 ; 4242$ respectively \\
& 2015,2018 & (total of 10,317) \\
Florida (FLA) & & 7,563 \\
Greensboro, NC (GRE) & 2018 & 5,314 \\
Louisville, KY (LOU) & 2015 & 6,346 \\
Melbourne, FL (MEL) & 2017 & 2,646 \\
Mississippi (MS) & 2016 & 5,866 \\
Mississippi River Delta (MRD) & 2016 & 6,665 \\
Palm Beach, FL (PLB) & 2016 & 5,276 \\
Roanoke, VA (ROA) & 2010 & 5,958 \\
Roanoke-New River Valley (RNV) & 2017 & 4,212 \\
Savannah, GA (SAV) & 2014 & 5,370 \\
Titusville, FL (TVL) & 2014 & 1,939 \\
West Virginia (WV) & 2016 & 4,674 \\
Total corpus word count & 2013 & 138,584 \\
\hline & &
\end{tabular}

searched root, so that a search of "south*" retrieves usages of southern, southeast, etc. While such distant reading allows us to note some variation in presence of the term across the profiles, it is important to understand the context as word usage may imply relative direction or a location and have little to do with invoking a sense of place through the articulation of Southern culture or the way of doing business. For example, the phrase, "upscale take on southern food, Empire State South- Helmed by Top Chef..." (Atlanta, 2013) merely names the restaurant. In the larger context it is clear that the restaurant is praised for the "...a more modern and upscale take on Southern food..." in the same passage, thus we counted that specific instance as a linkage to Southern culture. Other instances of the restaurant name in other later profiles were usually focused on the prominent chef and merely mentioned "south" in acknowledging the various restaurants the chef had started. Through this method of contextualizing search terms, distant reading begins to fall in line with close reading methods, allowing for more nuanced usage of the data in tracking discourse, the primary task undertaken in this paper.

While we have chosen to focus on written text, we acknowledge that these profiles are rich with images, advertisements and maps of these places that are excluded from this analysis. We do this in order to focus on what could be considered a dialect in place marketing efforts. Written text conveys information differently than the visuals and advertisements. One could 
argue that for the discourse, the written text would work in concert with the imagery. However, when reading a magazine, the text is a central component of the article, and as such, deserves attention.

\section{LEVERAGING THE SOUTH IN THE CORPUS}

"What makes Atlanta Atlanta? First, start with a Southern base of wellremembered history and heartfelt hospitality. Then, add in some international flare-scores of cultures influence the local food and arts scenes, and the city is home to the busiest passenger airport in the country, which pulses with a globe's worth of arrivals and departures each day." (ATL 2015)

“...Louisville defies expectations.

'We're not the deep South and we're not a monoculture."' (LOU 2017)

These two quotes signify a very interesting discursive dance that civic leaders and place promotion practitioners must perform. As discussed above, perceptions of the South are problematic, despite decades of regional growth as the Sunbelt rose in population and economic importance. Both quotes signify a certain distancing from the South, as the passage from the Atlanta 2015 profile resembles a recipe, using southern hospitality and sense of history as a base, but adds other ingredients invoking globalization and change. The quote for Louisville is from a chef discussing the feel of independent restaurants, but then shifts to describe Louisville in a way that explicitly distances the city from the "Deep South" and emphasizes the multiple cultures the speaker claims are present.
Table 3 shows the raw frequencies of the search term "south*", and a contextualized count where the authors performed a close reading to determine whether the term was part of a sentence articulating a southern identity. The ratio indicates the percentages of the results invoking regional identity.

The table show that in several profiles, the term south and attendant words resulting from the truncated search "south*", such as southern or southeast were not deployed to define the region explicitly. The profiles for the four Florida cities were low in southern references according to both raw and relative frequencies. The Columbia, SC raw data is skewed by the name of the state, but when examined in context, the number of coded mentions declines. Other profiles highlighted Southern identity, specifically all four Atlanta profiles, as did Baton Rouge, Columbia, Greensboro, Mississippi, the Mississippi River Delta, and Savannah. Conversely, the West Virginia profile uses the term "south" merely as a way to differentiate areas of Charleston or to provide a relative location within the state.

\section{Southern Cuisine}

Unsurprisingly, the use of "south" or "southern" in relation to culinary culture is found in multiple profiles, extolling a variety of foodstuffs. Savannah's profile highlights a restaurant's, “...blend of southern comfort and soul food with a strong emphasis on locally sourced organic ingredients...." (SAV 2014). This is an interesting melding of food types, as southern comfort food with soul food, the latter term associated with African-American culinary culture. The concept of comfort food is not necessarily African-American 
Table 3. Raw and contextualized counts of the terms south and southeast (through truncation) and ratios.

\begin{tabular}{lrrrrrc}
\hline & $\begin{array}{l}\text { South* } \\
\text { Frequency }\end{array}$ & $\begin{array}{l}\text { South* } \\
\text { contextualized } \\
\text { Frequency }\end{array}$ & & Ratio & $\begin{array}{l}\text { Southeast* } \\
\text { Frequency }\end{array}$ & $\begin{array}{l}\text { Southeast* } \\
\text { Contextualized } \\
\text { Frequency }\end{array}$ \\
\hline ATL2010 & 43 & 31 & $72.09 \%$ & 15 & 14 & $93.33 \%$ \\
ATL2013 & 55 & 37 & $67.27 \%$ & 12 & 7 & $58.33 \%$ \\
ATL2015 & 34 & 17 & $50.00 \%$ & 7 & 6 & $85.71 \%$ \\
ATL2017 & 36 & 29 & $80.56 \%$ & 10 & 9 & $90.00 \%$ \\
BAT2014 & 9 & 5 & $55.56 \%$ & 0 & 0 & N/A \\
COC2016 & 2 & 0 & $0.00 \%$ & 0 & 0 & N/A \\
COL2015 & 41 & 10 & $24.39 \%$ & 0 & 0 & N/A \\
COL2018 & 27 & 4 & $14.81 \%$ & 1 & 1 & $100.00 \%$ \\
FLA2018 & 17 & 4 & $23.53 \%$ & 4 & 2 & $50.00 \%$ \\
GRE2015 & 11 & 9 & $81.82 \%$ & 1 & 1 & $100.00 \%$ \\
LOU2017 & 10 & 3 & $30.00 \%$ & 0 & 0 & N/A \\
MEL2016 & 4 & 1 & $25.00 \%$ & 1 & 0 & $0.00 \%$ \\
MRD2016 & 21 & 16 & $76.19 \%$ & 1 & 0 & $0.00 \%$ \\
MS2017 & 11 & 7 & $63.64 \%$ & 0 & 0 & N/A \\
PLB2010 & 7 & 2 & $28.57 \%$ & 3 & 3 & $100.00 \%$ \\
ROA2017 & 15 & 3 & $20.00 \%$ & 0 & 0 & N/A \\
RON2014 & 8 & 3 & $37.50 \%$ & 0 & 0 & N/A \\
SAV2014 & 16 & 6 & $37.50 \%$ & 0 & 0 & N/A \\
TVL2016 & 1 & 1 & $100.00 \%$ & 1 & 1 & $100.00 \%$ \\
WV2013 & 6 & 0 & $0.00 \%$ & 0 & 0 & N/A \\
\hline
\end{tabular}

and the merging of the two would seem to revel in a specifically southern variant, and modern take on customer tastes with the emphasis on organic ingredients. The Roanoke-New River profile links southern to sweet tea. Special "Southern sweet and savory snacks..." are invoked in the Mississippi profile (MS 2017), with examples such as pepper relish and 'Southern Trash', a snack mix. The Mississippi River Delta profile discusses the combination of, "fried catfish, and barbecue.... but spicy Delta-style tamales are often on the menu too" (MRD 2016). There is a Delta Hot Tamale Trail that steers tourists to sample these relative newcomers to southern cuisine. Additionally, "the Delta region surely exceeds expectations when it comes to classic comfort foods" (MRD 2016).

Like any material aspect of culture, cuisine is not static. One interesting phenomena in the corpus is the merging of cuisines while simultaneously linking to a Southern flair. In discussing several chefs and restaurants, profiles highlighted individuals blending a variety of cuisines (e.g. Italian and Southern, combining wood-fired pizza with distinctly southern toppings such as pork-belly or salads with crispy chicken skins). Doing this signals 


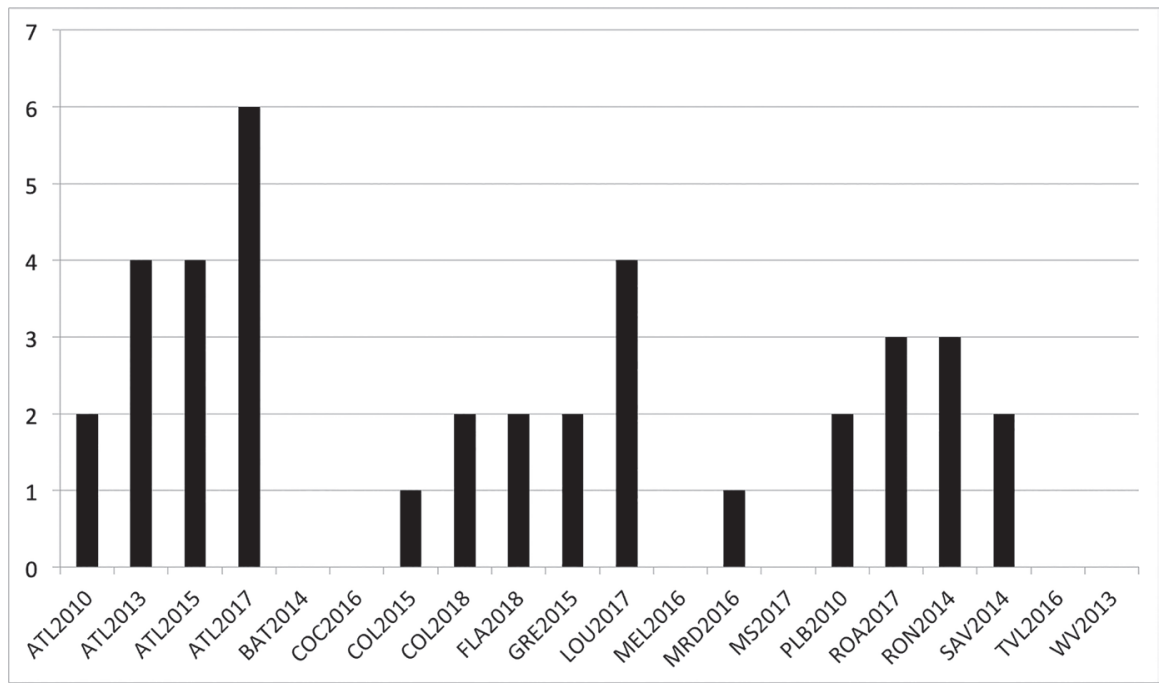

Figure 1. Number of times "quality of life" is mentioned in each profile.

an authentic Southern cuisine but still flags the cuisine as innovative. Others put a "southern spin on French bistro classics" (COL 2015). Another profile author calls the offerings at Greensboro's Lucky 32 Southern Kitchen as "southern flavored," (GRE 2015) highlighting the food pairing of coastal South Carolina's shrimp and grits with Cajun andouille sausage. This emphasis in the text of blending of cuisines is seen by the author as cutting-edge, and perhaps Cajun is seen as distinct from Southern foods. Barbecue figures prominently in the Mississippi Delta profile (mentioned twelve times), but only appears in four others, which is surprising given the pride that many Southerners take in their barbecue preferences (See Alderman and Caspersen 2018 for connections between race and barbecue in the South). Atlanta's 2017 profile used the headline, "From Fancy Fine Dining to Scrappy Pop-Ups, Atlanta's Culinary Community Embraces Trends and Traditions."
(ATL 2017). The dichotomy of the traditional cultural culinary base and the layering of new, non-southern cuisine represents an interesting cultural palimpsest that is clearly aimed at the high-end reader who may also be classified as a foodie.

\section{Quality of Life}

While not easily defined, the term "quality of life" (See Burgess 1982) also figures in the vast majority of the profiles (fourteen of twenty contained the phrase, see Figure 1) but is rarely defined with any precision but assumed to be almost selfevident as a variety of amenities, both physical and cultural, are discussed further in each profile. The phrase is often used by interviewees to justify why the profiled place works for their employees and their firms. While any definition of "quality of life" would incorporate various individual subjectivities that inform an understanding of place, there appears to be a 
common understanding across the profiles' authors that the quality of life in a location is an intangible factor in both attracting the creative class and for retaining talent.

Southern identity is often explicitly linked to the theme of a unique "quality of life" in the regional profiles, though what constitutes a "good quality of life" reflects myriad subjectivities. Still, it is no accident that the phrase appears so often in the corpus. Southern ways of life are conveyed through the explicit use of 'quality of life' and additional terms such as "charm" and "lifestyle." The Baton Rouge profile referred to the city as having, "...the appeal of a sultry Southern town combined with a dash of Cajun, a pinch of Creole, and a heaping spoonful of charm" (BAT 2014).

The term charm is applied specifically in conjunction with "Southern" or "Southern hospitality"4 in several instances, and in interesting juxtapositions such as a subheading, "Daytime charm and nighttime fun" (ATL 2015), implying the character of the place changed with the dark. Additionally, the pairing of charm with "small-town" was observed, which hearkens back to the point raised about the South attempting to retain the image of a slower lifestyle, different from the rest of the country. In the Roanoke profile, this connection is made explicit as a local business leader claims "employees are happy with the quality of life a small city offers", choosing to contrast Roanoke with the likes of San Francisco and New York (ROA 2017). Similarly, there seems to be an association in several of the profiles between quality of life and cost, specifically promising a higher quality of life for lower cost, something that contributes to the neoliberal promotion-driven gentrification of neighborhoods that Eisenschitz (2010) describes as "dependent on the creative class" (p.81). For example, Louisville "affords unmatched quality of life, alongside housing prices that are the envy of 'luxury cities' on the coasts", making a less than subtle jab at those aforementioned cities and extolling the benefits of low housing prices. Of the 38 results for "quality of life" in the corpus, eight (twenty-one percent) of them are used in conjunction with discussion of low costs of living in the profiled city. While this may be common to many cities' promotion efforts, these cities are nevertheless leveraging affordability in hopes of attracting more creative class talent.

The term lifestyle provides more insight to how the South is leveraged in terms of quality of life in the corpus. Lifestyle is used in only a limited capacity in the corpus (with only thirteen mentions of the word). The usage signals that the South offers a distinct way of life compared to larger and more expensive cities. The Atlanta profiles, which frequently evoke the South and Southeast, describe both an urban lifestyle and "the city's diversity of lifestyles", a phrase which follows a discussion of the city's neighborhoods, highlighting the fact that living in a home, as opposed to an apartment, is not uncommon (ATL 2015, ATL 2017). Some profiles take lifestyle in the other direction, as Greensboro describes the local lifestyle as "Southern", describing a transplant in the city who had embraced being "quick to wave hello and share a smile with strangers on the street" (GRE 2015).

Within the corpus, it is clear that lifestyles as they are being sold are not homogenous across the locations, though 
some, like Greensboro, choose to take advantage of conceptions of a friendly, intimate South that anyone can be a part of, should they choose to relocate to the city. Mississippi also sells the Southern, or more specifically, the Delta lifestyle to outsiders rather oddly, claiming that "travelers can experience a facsimile of the Delta lifestyle by staying overnight at the nearby Shack Up Inn, a collection of sharecropper shacks and farm buildings updated with electricity and running water" (MS 2017). The repurposing of sharecropper shacks, a part of the region's economic history, into a tourist destination claiming to reproduce the "Delta lifestyle" is one of the more puzzling marketing attempts in the profiles. The Shack Up Inn sells a taste of poverty. The Riverside Hotel entry, which is highlighted as "once the only African-American hotel in the region" fails to explain why such a hotel needed to exist during the Jim Crow period. Both properties illuminate the duality of place marketing, according to Short (1999) as Mississippi deals with the "shadow" of presenting the state in a flattering light, a shadow "that has to be contained, controlled, or ignored."

Another phrase of interest is "way of life." The usage varies, but three of the five instances emphasized specifically local ways of life. Savannah's profile links art to a way of life. The Mississippi River Delta interestingly adds developments of sustainable farming practices to a "way of life that is holding steady along the Mississippi." (MRD 2016) while the Mississippi profile discusses how the Delta lifestyles specifically supported the development of the blues in the region.

Thus, the profiles of Southern locations and claims to a particular quality of life, lifestyle or way of life vary depending on what market niche the authors are trying to reach. Each profile must emphasize its individuality and brand, while only some choose to take up the banner of a greater Southern identity as a marketing tool. Those that do, such as Mississippi, have to contend with the shadows that perceptions of the South cast while also bearing the burden of establishing individuality, a complicated prospect indeed.

\section{SELLING ECONOMIC GEOGRAPHY}

As illustrated above, not all profiles chose to evoke a sense of Southerness as a primary means of promoting place. Rather, profiles turned to less regionally specific place promotion strategies and embraced context-specific economic geographies. We have identified three such strategies that are being used in conjunction with or in lieu of southern identity: accessibility, innovation, and attracting the creative class.

\section{Accessibility and Relative}

\section{Distance}

The theme of accessibility surfaced after attempting to approach the issue of centrality in the corpus, following the place promotion literature going back to Burgess (1982). This search yielded little in terms of emphasizing geographic centrality in the South, signaling a shift in the discourse surrounding issues like logistics, to make way for a discussion of accessibility. Accessibility as a place marketing concept is not uniquely associated with the South and is primarily concerned with relative location insofar as it makes distance less of a barrier by way of infrastructure that facilitates 
movement of goods, people or ideas, or generates advantages from localized spatial relationships (i.e., agglomerations). Accessibility accounts for the increasingly important role of telecommunications in business today, and the time-space compression of distance (Harvey 1990). Accessibility also taps into the idea of agglomeration, the clustering of related firms or amenities that make a place desirable for business. In this case, authors can emphasize the relative distance between the promoted city and economic nodes, such as universities and firms. Additionally, in some cases, the number of nodes within the network of the profiled city can constitute agglomeration in itself. Place marketing campaigns appear to be converging toward a formula encouraging the adoption of generic characteristics (Warnaby and Medway, 2013) that are valued by decision makers. Because of this, it is unsurprising to see it articulated in the texts alongside infrastructure.

Accessibility was not easily parsed by Voyant, requiring a total of fourteen search terms for contextualization. Of these, two proved fruitful: "access" and "connect*". These terms reveal a continued emphasis on a variety of transportation networks with nodes in the profiled city, as well as "access to talent" which most often points to agglomerations in particular industries or firms that increase the flow of entrepreneurs, emphasizing a "creative class" easily within reach of the city or state.

The distinction between simple amenities and distinct references to geographic relationships is easily missed. While it may be understood that fifty-seven regional universities provide a talent pool to Atlanta, such text fails to establish a spatial relationship. However, it does signal a clustering of educational resources in a defined region and denotes support of business by supplying an educated workforce.

Relative distance, the first area of concern, is linked to transportation and telecommunication infrastructure, e.g. interstate highways and high-speed internet lines, such that the Greensboro profile touts, "Five interstate highways feed the airport now and connectors are under construction that will add even more access for industrial sites with a need for immediate highway access" (GRE 2015). An advantage that cities like Atlanta extol in promotion is superior air connections, noting that "[Highways and HartsfieldJackson Airport] alone make it easy for companies to reach more than 80 percent of the US industrial, commercial and consumer markets in two days or less by truck-and two hours by air" (ATL 2010). This claim sells Atlanta as a hub for reaching American markets, despite not being geographically central to the US in a literal sense. Rather, the profile sells the idea of connectivity in Atlanta, that Atlanta has advantages significantly reducing the barrier of distance across the US.

\section{Agglomeration and Clustering}

The other consideration in evaluating access is agglomeration and clustering (Porter, 1998; Delgado, et al. 2010, though see Woods and Roberts, 2011, pp. 133-134 for a critique of these as explanations of localized growth), the localization of firms and services that can contribute to talent pools or drive economies of scale within the analytical region (region, state, metro, etc.). One common example is education clusters or clusters 
such as the medical service agglomeration centered on Emory University and the Centers for Disease Control and Prevention in Atlanta. These networks often have global reach due to the significant pull factors that create institutions like the medical cluster, such that Atlanta medical startups are granted access to global health conglomerates and talent from around the world. This focus on agglomeration and the description of the nodes that form a network are what distinguish the idea of accessibility from centrality and connectivity.

Every profile includes some characterization of the space as well positioned, connected, and agglomerated. The 2010 Atlanta profile explicates this sort of relationship as a promotion of the metro: “Thriving corporations aren't just drawn to the region by its outstanding infrastructure, [etc.] ... and a transportation network that offers unequaled access to the world. They're grown here." (ATL 2010). The implications of such a statement are twofold. Noting the transportation infrastructure and associated pull factors, the profile appeals to businesses wishing to relocate while also portraying a smaller scale accessibility to entrepreneurs who may not yet be established, including internal talent. Additionally, Atlanta is sold as a site of critical agglomeration, where pull factors and connectivity incubate homegrown industries and innovation that then has access to the agglomerations that incubated it in the first place. This sort of internal accessibility sells an innovative workforce to potential firms, such that by simply being in Atlanta, the firm gets exposure and priority access to new and exciting innovation.
Beyond Atlanta, locations like Palm Beach similarly sell "coveted universities and colleges, connections to potential capital at every turn and its enviable location (providing access to companies through its numerous ports and three nearby international airports)" meaning agglomerations of transportation nodes, universities, and amenities in one package for the consumer considering a move (PLB 2010). Similarly, Louisville emphasizes its status as a node with multiple types of connectivity, even beyond land and air travel as it boasts "an international airport, a major UPS hub, as well as easy access to interstates, buses, trains, and Ohio River transportation" (LOU 2017). The inclusion of river transport, as well as highlighting UPS's presence, is targeted explicitly at business. The profile sells connectivity and accessibility as a logistic advantage while a variety of transportation modes make the Louisville node more desirable.

Other profiles did not discuss agglomeration or access in the same way as those highlighted above. Baton Rouge's profile specifically speaks of petroleum and chemical processing agglomeration, fueled by a pipeline, as well as a talent pool built around Louisiana State University. However, the reach of Baton Rouge as described in the short profile does not make claims to its access to nodes beyond itself. The Mississippi profile touches on elements of accessibility in recounting the recent development of the state's "Golden Triangle" region, questioning why the region was not thriving despite "the railroads, the waterways, and a workforce that was just waiting on jobs" (MS2017). The author highlights the Golden Triangle Development LINK role in developing 
a network of industries, namely leveraging the aerospace industry and access to quality higher education institutions. These combine to portray Mississippi as an attractive, connected node in an economic network, emphasizing rail and freshwater waterways over interstates and air travel.

What we have demonstrated above is the marketing of specific place characteristics such as accessibility and relative location highlighted in the literature as far back as the 1980s, has persisted, reflecting the homogenization and formation of an epistemic community that is fluent in what place characteristics must be highlighted to attract positive attention. What has changed is the addition of another layer of concerns for place marketers namely the idea of local, entrepreneurial, and even innovative cultures as an important lure.

\section{Selling the South as}

an Innovative and

Entrepreneurial Place

In an attempt to sell the profiled locations as desirable nodes in a larger economic world, the selected profiles tended to emphasize innovation, entrepreneurship, and technology as the drivers of prosperity in the featured locations. With the exception of only the Savannah and Mississippi profiles, every profile uses the word innovative or innovation as a marker for economic development potential or in describing the amenities of the location. The Roanoke-New River Valley profile attributes economic renewal and the combatting of brain drain to "an explosion of entrepreneur-driven tech companies that have created a cascading effect that is spurring more innovation and economic diversity", a phrase not entirely out of place in a boardroom meeting on workplace synergy (RON 2014). Meanwhile, the authors of the profiles frequently quote business leaders touting much the same message, that "Vibrancy, creativity, and innovation are really starting to turn in our community" can be found describing Tallahassee-Leon County, just as easily as it can describe Atlanta, a place where "The whole innovation ecosystem has always existed" (FLA 2018, ATL 2017). The emphasis on innovation and entrepreneurship sells a future-forward approach to economic development, promising conditions and potential for sustained growth. Both innovation and entrepreneurship then propose an endless march of technological progress to overturn any perception of the South as economically stagnant or backwards. This idea is not uncommon and situates entrepreneurs as a primary agent in the local economy, a nod to the existence of a creative class central to progress (Florida, 2002), and the need to create the conditions to attract that creative class in terms of amenities (discussed below). The profiles follow suit frequently mentioning institutions like the Greensboro Partnership or the McNair Center for Entrepreneurism within the profile, in hopes that "a community of innovators attracts other innovators", as the 2017 Atlanta profile claims in covering the rising financial technology sector in the city (GRE 2015, COL 2015, ATL 2017). This paradigm is duplicated across the profiles, reinforcing a neoliberal order to economic growth and promotion where the logic of synergy and creating a space for synergy to happen is sold.

With only one mention of innovation between them, the Mississippi River Delta and Mississippi profiles lack many of these buzzwords compared to the others. 
Searching for "entrepren*" finds its way into the River Delta profile, with six out of seven hits occurring in the last feature, highlighting workforce quality. Mississippi has even fewer, with zero mentions of either innov* or entrepren* across the entire document. This divergence from the established pattern does make the profiles stand out, for better or worse. The Mississippi and Mississippi River Delta profiles emphasize the tourism industry to a greater degree, not just in number of words dedicated to the topic, but even the forward placement within the profiles. ${ }^{2}$ The possible explanations for this divergence include an attempt to sell the nodes' cultural amenities over their manufacturing ones, so as to emphasize tourism as an industry; or perhaps cynically, it indicates that the region has simply been left behind in terms of place-marketing strategy employed by the institutions providing information to Sky's authors.

\section{Attracting the Creative Class}

As a means of marketing innovation and entrepreneurial spirit, some local government approaches to development have incorporated Richard Florida's idea of a creative class. The concept has been influential since Florida's, The Rise of the Creative Class: And how it's Transforming Work, Leisure, Community and Everyday Life was published in 2002. (Florida, 2002). The premise that members of the creative class want vibrant cities with things to do shifts how entrepreneurial cities go about supporting growth. As a Salon writer paraphrased the idea, the policy implications were "...the leadership should instead develop an environment attractive to the creative class by cultivating the arts, music, nightlife and quaint historic districts — in short, develop places that are fun and interesting rather than corporate and malllike" (Dreher 2002). Geographers have cogently critiqued the idea of the creative class (see Peck 2005) but the corpus texts reflect that Florida was a successful intellectual entrepreneur and the language of what allegedly attracts the creative class permeates the profiles. The Roanoke profile clearly argues that their efforts to rethink natural recreation opportunities have helped in the chase for talent:

"The mountains, rivers and lakes were always here, but we treated them like wallpaper,' says Beth Doughty, executive director of the Roanoke Regional Partnership. 'By igniting those assets, we were able to change the community narrative in a short period of time.' That effort results not just in investment and jobs, she points out-it pays off in talent attraction. "Talent is the currency of the 21st century,' she adds" (emphasis ours, ROA 2017). An earlier profile that paired Roanoke with the New River Valley highlighted how important outdoor amenities were. The Roanoke Regional Partnership had a "director of outdoor branding" who argued that the outdoors was an unused asset, one that could raise perceptions of the local quality of life (RON 2014) and combat a perception of being a peripheral location.

Louisville's profile quotes the president of a Danish firm discussing the ease of attracting engineers, saying, "When the company recruits engineers, he adds, the city's expanding cultural scene has helped young professionals decide to stay and grow roots. "We [have] really had a good run as far as retaining employees," he says. "Eighteen years ago, I could imagine a lot of younger people graduating would have left Louisville." (LOU 2017) 


\section{CONCLUSION}

With almost every profile trying to sell a place as innovative and entrepreneur friendly, there is a reduction of these characteristics down to generic boilerplate. Branding a place is dependent on creating an affective distinction, a process that eventually results in an implicit formula as place promoters seek to capture similar markets' interests (Boisen, et al. 2018). This convergence is observed as early as the 1980s with Burgess relating the confessions of a public relations officer, stating that, "I've been in this business long enough to know that many of the things I have said about this town, I have said about elsewhere." (Burgess 1982, p. 6). The entire process of selling the South hardly seems innovative when the structure can be boiled down to buzzwords, their synonyms, and talking points.

As Warnaby and Medway (2013) point out, scholars make clear there is a, "... lack of distinctiveness of place marketing campaigns, regardless of the intrinsic nature of the places themselves.... that place marketing activities inevitably channel places into a competitive zero-sum game, where the formula(e) for success are similar if not identical." (Warnaby and Medway 2013, p. 347). Our review of the corpus shows that several themes are invoked across the twenty $S k y$ profiles, reflecting the development of an epistemic community of practitioners (e.g. economic development professionals as well as the authors for the magazine) that understand the audience the profiles are intended to reach. As discussed earlier, if Sky has a niche audience, the authors must communicate in terms that will grab their attention. Various forms of comparative advantage such as accessibility, potential for attracting talent, and agglomerations feature prominently. For other niches, the generic "quality of life" and "lifestyles" that the profiles define, vary depending on whether the goal is attracting the creative class, water recreation enthusiasts, food and drink tourists, or history and music buffs.

The branding of many of these locations, especially economically, has a homogenizing effect upon some of the advantages presented by the profiled location. However, there exists evidence at least in profiles such as Atlanta, that the South as a geographic region is a marketable commodity. As Cobb (1993) points out, selling the South is a challenge and our analysis demonstrates that for most of the profiled locations, an association with the South is an issue that must be addressed. Even when it is not invoked directly, the connotations of being Southern are highlighted and leveraged to define place, such as the presence of Southern cuisine, or eschewed and redefined, with profiles claiming that they are merely peripheral to the South, as the profile of Louisville chose to do. This selective invocation of specific elements of Southerness is part and parcel of place promotion efforts, communicating a positive image of the region.

Concerning the connections to a Southern identity as leveraged for place promotion, it should be clear that the views presented in the profiles are created by interests vested in the promotion of the place to a specific audience. The reduction of place characteristics to the generic that occurs with place branding often results in a single-faceted view of the place showing only the most polished and flattering angle. Behind this representation, Clegg and Kornberger speak of “... a struggle 
between a brand and its homogenous, silencing effects, and the overflowing, polyphonic reality of people's interpretations of a place" (Clegg and Kornberger 2010, as cited in Warnaby and Medway 2013 p.347). The concept of the South as a cultural region is such a homogenization that is in competition with more generic views of development. Both are necessary to effectively communicate to both tourists and businesses looking to relocate or expand.

The visual advertisements in these profiles were excluded from the analysis. Noting the partial nature of place marketing efforts, what is included in visual materials also matters. While the written word extols the virtues of proximity to mountains in the New River profile, and beaches are featured in the various Florida profiles, images of these physical features are powerful. Additionally, as Alderman and Modlin (2012) point out, the issue of race in promoting the South via pictures is still present. It is possible that our focus on written text has shortchanged the impact of the visual on Sky's readership. How themes identified from the literature play out visually or cartographically is of interest. Further work should explore what the choice of photos means for representing the South's diversity (or lack thereof in certain locales). What landscape features are invoked to reinforce "Southerness?" What cartographic manipulations are made to render southern places seemingly accessible? Finally, as the advertisements contain written text that differs in form from the written articles examined here, further work on the advertisements may reveal a different approach to selling the South.

\section{NOTES}

1. For our purposes, we examine profiles highlighting areas of states of contained in the
SEDAAG region plus profiles of Baton Rouge, Louisiana and the Mississippi River Delta (a region defined by a federal-state partnership known as the Delta Regional Authority, which adds portions of Arkansas, Missouri and Illinois to the dataset).

2. Most of the profiles in the corpus are headed by an article describing the business climate of the profiled location, highlighting firms and resources present. Another section is often devoted to business in general. Institutions of higher education are often profiled next, followed by discussion of tourism and recreation possibilities.

3. In 2013 Sky magazine had the greatest circulation of all American airlines inflight magazines, at 601,383 . United's Hemispheres had 576,000. Southwest Airlines Spirit had a circulation of 447,928 .

4. Surprisingly, only six of the twenty profiles mentioned "southern hospitality" as a selling point for the local culture.

\section{ACKNOWLEDGEMENTS}

The authors wish to thank two anonymous reviewers and the editors for their helpful suggestions.

\section{REFERENCES CITED}

Ambrose, A. "Atlanta." New Georgia

Encyclopedia. 26 July 2017. https://www

.georgiaencyclopedia.org/articles/

counties-cities-neighborhoods/atlanta

Web. 2 July 2018.

Alderman, D. H. and Good, D.B.1997.

Exploring the virtual South: The idea of a distinctive region on 'the Web"'. Southeastern Geographer 37(1): 20-45

Alderman, D.H. and Modlin, E.A. 2012.

Southern hospitality and the politics of African American belonging: an analysis of North Carolina tourism brochure photographs. Journal of Cultural Geography 30(1): 6-31 
Alderman, D.H., and Caspersen, J. 2018. Barbecue tourism. In Tourism Experiences and Animal Consumption: Contested Values, Morality and Ethics, ed. Carol Kline, pages 102-118. London: Routledge.

Ayers, E.L. 1996. What we talk about when we talk about the South. All Over the Map: Rethinking American Regions. Pages 62-82. The Johns Hopkins University Press, Baltimore and London.

Beauguitte, L., Richard, Y., and Guérin-Pace, F. 2015. The EU and its neighbourhoods: A textual analysis on key documents of the European Neighbourhood Policy. Geopolitics 20(4): 853-879

Birdsall, S.S. 1986. Changing images of the tourist South since 1950. Southeastern Geographer 26(2):135-143.

Boisen, M., Terlouw, K., Groote, P., and Couwenburg, O. 2018. Reframing place promotion, place marketing, and place branding - moving beyond conceptual confusion. Cities 80:4-11

Burgess, J.A. 1982. Selling places: environmental images for the executive. Regional Studies 16(1): 1-17.

Cision Staff. 2013. "Top 10 Inflight Magazines.” https://www.cision.com/us/2013/03/top10-airline-inflight-magazines-2/. Accessed December $4^{\text {th }}, 2018$.

Clegg, S. and Kornberger, M. 2010. An Organizational Perspective of Space and Place Branding. In International Place Branding Yearbook 2010: Place Branding in the New Age of Innovation, ed. M. Go and R. Govers, 3-11. Houndmills, UK: Palgrave Macmillan.

Cobb, J.C. 1993. The Selling of the South: the Southern Crusade for Industrial Development, 1936-1990. Urbana and Chicago: University of Illinois Press.

Cox, K.L. 2011. Dreaming of Dixie: How the South Was Created in American Popular
Culture. Chapel Hill, NC: University of North Carolina Press.

Delgado, M., Porter, M. E. and Stern, S. 2010. Clusters and entrepreneurship. Journal of Economic Geography 43:1785-1799.

Dreher, C. 2002 Be creative - or die. Salon. https://www.salon.com/2002/06/06/ florida_22/[Accessed July 20, 2018]

Eisenschitz, A. 2010 Neo-liberalism and the future of place marketing. Place Branding and Public Diplomacy 6(2):79-86

Florida. R. 2002. The Rise of the Creative Class: And how it's Transforming Work, Leisure, Community and Everyday Life. Basic Books: New York.

Goss, J.D. 1993. Placing the market and marketing place: tourist advertising of the Hawaiian Islands, 1972-1992. Environment and Planning D: Society and Space 11:663-688

Guzman, G.G. 2017. Household Income 2016. American Community Survey Briefs. U.S. Census Bureau. https://www.census .gov/content/dam/Census/library/ publications/2017/acs/acsbr16-02.pdf. [Accessed July 30, 2018.]

Harvey, D. 1989. From managerialism to entrepreneurialism: The transformation in urban governance in late capitalism. Geografiska Annaler 71: 3-17

Harvey, D. 1990. The Condition of Postmodernity: An Enquiry into the Origins of Cultural Change. Cambridge, MA: Blackwell.

Kirsch, A. 2014. Technology is taking over English Departments: the false promise of digital humanities. The New Republic. May 2. https://newrepublic.com/ article/117428/limits-digital-humanitiesadam-kirsch. Accessed June 28th, 2018.

Lefebvre, H. 1971. The Production of Space. (Translated by Nicholson-Smith, D, 1992). London: Wiley-Blackwell. 
Moretti, F. 2013. Distant Reading. New York: Verso.

Peck, J. 2005. Struggling with the creative class. International Journal of Urban and Regional Research 29(4): 740-770.

Peck, J. and Tickell, A. 2002. Neoliberalizing space. Antipode 34(3): 380-404

Purcell, D. and Kodras, J. 2001 Information technologies, representational spaces, and the marginal state: Redrawing the Balkan image of Slovenia. Information, Communications and Society 4(3): 1-29.

Rockwell, G. and Sinclair, S. 2016. Hermeneutica: Computer-assisted Interpretation in the Humanities. Cambridge, MA: The MIT Press.

Ryan, C. L and Bauman, K. 2016. Educational attainment in the United States: 2015 population characteristics. Current Population Reports. US Census Bureau. https://www.census.gov/content/dam/ Census/library/publications/2016/demo/ p20-578.pdf. [Accessed July 30, 2018]

Ryan, K. Bruce. 1990. The "Official” Image of Australia. In Place Images in Media: Portrayal, Experience, and Meaning. Ed. L. Zonn, 135-158. Maryland: Rowman \& Littlefield Publishers

Short, J.R. 1999. Urban Imagineers: Boosterism and the Representation of Cities. In The Urban Growth Machine: Critical Perspectives Two Decades Later, ed. A.E.G. Jonas and D. Wilson, pages 37-54. New York: State University of New York Press.

Sky Mediakit. 2017. http://deltaskymag .delta.com/Magazine/Advertise-With-Us/ Downloads/Public/2017MediaKit_ROB_ LR-(1).pdf. Downloaded March 14th, 2018.
Voyant-tools.org. n.d. [Accessed May 16, 2018].

Ward, S.V. 1998. Selling Places: The Marketing and Promotion of Towns and Cities 1850-2000. London: E \& F SPON.

Warnaby, G. and Medway, D. 2013. What about the 'place' in place marketing? Marketing Theory 13(3): 345-363.

Webster, G.R. and Leib, J.I. 2016. Religion, murder, and the Confederate battle flag in South Carolina. Southeastern Geographer 56: 29-37.

Woods, A. and Roberts, S. 2011. Economic Geography: Places, Networks and Flows. New York: Routledge.

Young, C. and Lever, J. 1997. Place promotion, economic location and the consumption of city image. Tijdschrift voor Economische en Sociale Geografie 88(4): 332-341.

Zonn, L. 1990. Place Images in the Media: A Geographic Appraisal. Savage, MD: Rowman and Littlefield

DARREN PURCELL (dpurcell@ou.edu) is an Associate Professor in the Department of Geography and Environmental Sustainability at the University of Oklahoma in Norman, Oklahoma, 73019. His research interests include place promotion and place marketing, as well as popular geopolitics.

CAYTON MOORE (cayton.t.moore-1@ou.edu) is a Master's student in the Department of Geography and Environmental Sustainability at the University of Oklahoma in Norman, Oklahoma, 73019. His research interests include critical geopolitics, text and discourse analysis, and place promotion, with an emphasis on the Middle East and North Africa. 